\title{
PENGARUH GAYA KEPEMIMPINAN DAN KOMUNIKASI \\ TERHADAP KINERJA ORGANISASI PADA PRODI DILUAR DOMISILI (PDD) JEMBRANA POLITEKNIK NEGERI BALI (Rintisan Akademi Komunitas Negeri Jembrana)
}

\author{
Ni Komang Ardety Pramesti Indahsari ${ }^{1}$ \\ IKetut Merta ${ }^{2}$ \\ I Made Anom Arya Pering ${ }^{3}$
}

\author{
Program Studi Manajemen, Fakultas Ekonomi, \\ Universitas Mahendradatta Bali \\ Jl. Ken Arok No. 12 Peguyangan Denpasar Utara, Bali 80115 \\ ardetypramesty@gmail.com
}

\begin{abstract}
ABSTRAK
Penelitian ini berjudul Pengaruh Gaya Kepemimpinan dan Komunikasi terhadap Kinerja Organisasi. Mengambil Objek Penelitian Pada Prodi Diluar Domisili (PDD) Jembrana Politeknik Negeri Bali (Rintisan Akademi Komunitas Negeri Jembrana). Tujuan penelitian ini untuk mengetahui lebih mendalam tentang Gaya kepemimpinan, Komunikasi dan Kinerja Organsasi Rumusan masalah: apakah Gaya kepemimpinan dan Komunikasi berpengaruh terhadap Kinerja Organisasi. Landasan teori dalam penelitian memakai toeri Manajemen. Metodelogi: Papulasi dan sempel dengan 35 responden, menggunakan daftar kuesioner dan di tabulasi kemudian di analisis dengan regresi berganda menggunakan program SPSS versi 24. Hasil analisis Gaya Kepemimpian menghasilkan: t hitung sebesar 9.185dan signifikansi sebesar 0,000. thitung 9.185> t tabel yang nilainya 1.69 dengan tingkat signifikansi $0.736>0,05$. Komunikasi menghasil t hitung sebesar -1.922 dan signifikansi sebesar 0.064. $\mathrm{t}$ hitung $-1.922>\mathrm{t}$ tabel yang nilainya 1,69 dengan tingkat signifikansi $0,736>0,05$. Hipotesi diterima dengan $t$ hitung $7.263>t$ tabel 0.736 , maka hipotesis yang menyatakan adanya pengaruh yang positif signifikan antara Gaya Kepemimpinan dan Komunikasi terhadap Kinerja Organisasi Implikasi koefisien determinasi (adjusted R) yang diperoleh sebesar $75.4 \%$ menunjukkan bahwa Gaya Kepempinan dan Komunikasi terhadap Kinerja organisas sebesar $75.4 \%$ dan sebesar 24.6\% Gaya Kepempinan dan Komunikasi dipengaruhi oleh variabel-variabel lainnya yang tidak diteliti dalam penelitian ini serta dapat diteliti lebih lanjut.
\end{abstract}

Kata kunci : Gaya Kepemimpinan dan Komunikasi dan Kinerja Organisasi

ABSTRACT - This research is based on the Effect of Leadership and Communication Style on Organizational Performance. Taking the Object of Research at the Study Program Outside Domicile (PDD) Jembrana Bali State

Ni Komang Ardety Pramesti Indahsari

IKetut Merta

I Made Anom Arya Pering 
Polytechnic (Pilot Academy of the Jembrana Country Community). The purpose of this study is to find out more about leadership style, communication and organizational performance Problem formulation: whether leadership style and communication affect organizational performance. The theoretical foundation in research uses the Management Document. Methodology: Papulation and sampling with 35 respondents, using a questionnaire list and tabulated then analyzed by multiple regression using SPSS version 24. The results of the analysis of Leadership Style yield: $t$ count of 9.185 and significance of 0.000. $t$ count 9.185> t table whose value is 1.69 with a significance level of 0.736>0.05. Communication produces $t$ count of -1.922 and significance of 0.064. $t$ count $-1.922>t$ table whose value is 1.69 with a significance level of 0.736>0.05. Hypothesis is accepted with t count 7.263> t table 0.736, then the hypothesis which states that there is a significant positive influence between Leadership Style and Communication on Organizational Performance. The implications of the coefficient of determination (adjusted R) obtained by $75.4 \%$ indicate that the Leadership and Communication Style of organizational performance $75.4 \%$ and as much as $24.6 \%$ Leadership Style and Communication are influenced by other variables not examined in this study and can be further investigated.

Keywords: Leadership and Communication Style and Organizational Performance

\section{PENDAHULUAN}

Penyelenggaraan Program Studi Diluar Domisili (PDD) berdasarkan Peraturan Menteri Pendidikan Nasional Republik Indonesia Nomor 20 Tahun 2011 Tentang Penyelenggaraan Program Studi Diluar Domisili Perguruan Tinggi (Depdiknas, 2011). Didalam Permen tersebut sudah dijelaskan secara jelas bagaimana universitas bisa membuka PDD. Salah satu syarat mutlaknya adalah perguruan tinggi penyelenggara program studi di luar domisili telah memperoleh akreditasi A untuk program studi yang sama di domisili perguruan tinggi tersebut, kemudian penyelenggaraan program studi diluar domisili didukung oleh pemerintah daerah kabupaten/kota setempat.

Setiap perusahaan atau Perguruan Tinggi Negeri dan Swasta yang didirikan pada umumnya memiliki suatu tujuan yang jelas, baik itu tujuan jangka pendek, menengah maupun jangka panjang. Tujuan tersebut biasanya berorientasi pada perolehan pendapatan atau laba yang sebesar-besarnya dan berusaha mempertahankan eksistensi perusahaan tersebut. Untuk mewujudkan tujuan tersebut perusahaan memanfaatkan berbagai faktor produksi yang dimilikinya, seperti sumber daya alam, sumber daya manusia, modal dan kemampuan (skill).

Sumber daya $\begin{array}{r}\text { manusia } \\ \text { tentang }\end{array}$
merupakan pengakuan
pentingnya tenaga kerja organisasi
sebagai sumber daya manusia yang
sangat penting dalam memberi
kontribusi bagi tujuan-tujuan
organisasi, dan menggunakan
beberapa fungsi dan kegiatan untuk
memastikan bahwa sumber daya

Ni Komang Ardety Pramesti Indahsari

IKetut Merta

I Made Anom Arya Pering 
manusia tersebut digunakan secara efektif dan adil bagi kepentingan individu, organisasi, masyarakat (Schuler: 2014). Dengan demikian dapat dikatakan bahwa di dalam perusahaan sumber daya manusia merupakan modal dasar dalam menentukan tercapainya tujuan perusahaan. Berbagai cara dan pendekatan dapat dilakukan untuk meningkatkan kualitas sumber daya manusia pada karyawan di suatu perusahaan diantaranya adalah gaya kepemimpinan dan komunikasi yang efektif antara atasan dengan bawahan dan bawahan dengan sesama karyawan.

Berdasarkan hasil Survei Keluarga Miskin Tahun 2013, jumlah penduduk miskin di Kabupaten Jembrana sebanyak 16.806 jiwa atau $5,24 \%$ dari jumlah penduduk. Tingginya angka kemiskinan juga dapat dilihat dari tingginya jumlah rumah tangga miskin yang ada di Kabupaten Jembrana. Menurut data pada akhir Tahun 2013, terdapat 5.284 rumah tangga miskin. Kondisi ini menunjukkan bahwa tingkat kesejahteraan masyarakat Jembrana masih relatif rendah.

pengangguran, pada akhir tahun 2013 terdapat 4.245 penduduk yang tidak bekerja/menganggur. Tingginya angka pengangguran disebabkan karena banyak penduduk usia produktif tidak memiliki kualifikasi pendidikan dan kompetensi yang dibutuhkan oleh dunia usaha dan dunia industri, khususnya yang ada di Kabupaten Jembrana. Disamping itu, minimnya minat untuk berwiraswasta yang dimiliki oleh masyarakat Jembrana juga menjadi penyebab tingginya angka pengangguran. Sebagian besar masyarakat tidak ingin menciptakan usaha sendiri. Hal ini disebabkan karena mereka tidak memiliki wawasan dan kemampuan untuk melihat peluang usaha.

Masalah selanjutnya adalah masalah pada bidang pendidikan, yaitu rendahnya angka melanjutkan ke perguruan tinggi. Jumlah lulusan SMA/SMK di Kabupaten Jembrana tahun 2013 adalah sebanyak 11.556 orang. Dari lulusan tersebut, hanya 2.773 orang (hanya 24\%) dapat melanjutkan ke perguruan tinggi negeri/swasta, 5.437 orang $(47 \%)$ tidak melanjutkan dan 3.351 orang (29\%) bekerja. Lulusan yang tidak melanjutkan ke perguruan tinggi umumnya disebabkan oleh faktor ekonomi serta minimnya perguruan tinggi yang ada di Kabupaten Jembrana sehingga mereka tidak mampu untuk melanjutkan ke luar daerah.

Untuk menyelesaikan masalahmasalah yang dihadapi, Pemerintah Kabupaten Jembrana telah mengambil berbagai langkah-langkah kebijakan yang terencana dan efektif, salah satunya adalah dengan meningkatkan kualitas sumber daya manusia melalui pendidikan yang memadai dan berkualitas. Banyak kebijakan dan inovasi dalam bidang pendidikan yang telah dilaksanakan oleh Pemerintah Kabupaten Jembrana. Salah satu yang terpenting adalah memberikan subsidi pendidikan bagi siswa sekolah dasar maupun menengah setiap tahun. Dengan biaya subsidi ini, siswa tidak perlu membayar biaya pendidikan selama mereka mengikuti proses pendidikan di lembaga pendidikan, baik sekolah negeri maupun swasta. Disamping itu, Pemerintah Kabupaten Jembrana juga memberikan beasiswa bagi mahasiswa/mahasiswi perguruan tinggi negeri dan swasta dari

Ni Komang Ardety Pramesti Indahsari

IKetut Merta

I Made Anom Arya Pering 
Kabupaten Jembrana yang berprestasi. Namun demikian, semua langkah tersebut belum mampu sepenuhnya meningkatkan kualitas sumber daya manusia di Kabupaten Jembrana sesuai dengan yang diharapakan, karena akses untuk melanjutkan ke pendidikan yang lebih tinggi (Perguruan Tinggi) masih sulit mengingat tidak terdapat perguruan tinggi di Kabupaten Jembrana. Sehubungan dengan hal tersebut, Pemerintah Kabupaten Jembrana berharap agar didirikan sebuah perguruan tinggi di Kabupaten Jembrana sehingga jenjang pendidikan tinggi dapat mudah diakses oleh semua lapisan masyarakat Jembrana.

Dengan memperhatikan Undang-Undang Nomor 12 Tahun 2012 tentang Pendidikan Tinggi, Pemerintah Kabupaten Jembrana mengusulkan pendirian sebuah lembaga pendidikan tinggi dalam bentuk Akademi Komunitas (AK). Pendirian Akademi Komunitas di Kabupaten Jembrana sangat mungkin dilakukan karena Kabupaten Jembrana memiliki potensi pendukung, seperti besarnya jumlah penduduk usia produktif, yaitu mencapai 220.383 jiwa, tingginya jumlah lulusan SMA/SMK, yaitu 11.556 orang, tersedianya potensi daerah yang perlu dikembangkan dan tersedianya industri yang dapat menampung lulusan.

Selain untuk memberikan akses pendidikan tinggi yang lebih mudah, keberadaan Akademi Komunitas ini nantinya diharapkan dapat mencetak lulusan yang dapat mengelola dan mengembangkan potensi daerah yang dimiliki, yaitu potensi sektor pertanian, perikanan dan pariwisata sehingga potensi daerah tersebut dapat dikelola dan dimanfaatkan secara maksimal, dan pada akhirnya masalah-masalah yang dihadapi, seperti kemiskinan dan pengangguran dapat teratasi.

Namun

demikian, mempertimbangkan kelebihan dan kekurangan masing-masing potensi dan keterkaitan dengan Masterplan Percepatan dan Perluasan Pembangunan Ekonomi Indonesia (MP3EI), di awal pendirian, Akademi Komunitas ini agar diprioritaskan untuk dapat mencetak lulusan yang memiliki keterampilan di sektor pariwisata, khususnya bidang perhotelan. Untuk itu, program studi yang diusulkan dan diterima terkait dengan sektor pariwisata, khususnya bidang perhotelan, dengan Program Studi D1 Perhotelan yaitu:

1. Kosentrasi Kantor Depan (Front Office).

2. Kosentrasi Tata Hidangan (Food and Beverage Service).

3. Kosentrasi Tata Graha (Housekeeping).

Kinerja adalah hasil atau tingkat keberhasilan seseorang secara keseluruhan selama periode tertentu dalam melaksanakan tugas dibandingkan dengan berbagai kemungkinan, seperti standar hasil kerja, target atau sasaran atau kriteria yang telah ditentukan terlebih dahulu telah disepakati bersama (Rivai, 2005). Keberhasilan suatu organisasi dipengaruhi oleh kinerja pegawai atau hasil kerja yang dicapai oleh seorang pegawai dalam melakukan tugas sesuai dengan tanggung jawab yang diberikan kepadanya. Penilaian kinerja adalah proses mengevaluasi seberapa baik karyawan melakukan pekerjaan mereka jika dibandingkan dengan seperangkat standar, dan kemudian mengkomunikasikan informasi tersebut kepada karyawan. Penilaian kinerja juga disebut

Ni Komang Ardety Pramesti Indahsari

IKetut Merta

I Made Anom Arya Pering 
pemeringkatan karyawan, evaluasi karyawan, tinjauan kerja, evaluasi kinerja, dan penilaian hasil. Penilaian kinerja adalah proses penilaian ciriciri kepribadian, perilaku kerja, dan hasil kerja seseorang tenaga kerja atau pegawai (pekerja dan manajer), yang dianggap menunjang untuk kerjanya, yang digunakan sebagai bahan pertimbangan untuk pengambilan keputusan tentang tindakan-tindakan terhadap bidang ketenagakerjaan.

Tabel 1.1

Jumlah Pendidik dan Karyawan

Prodi Diluar Domisili (PDD) Jembrana

Politeknik Negeri Bali - Rintisan Akademi

Komunitas Negeri Jembrana Tahun 2018

\begin{tabular}{|l|l|l|l|}
\hline No & Pekerjaan & Jumlah & Persentase \\
\hline 1 & SLTA & 10 & $28,6 \%$ \\
\hline 2 & D III & 10 & $28,6 \%$ \\
\hline 3 & SI. & 10 & $28,6 \%$ \\
\hline 4 & S2 & $\mathbf{5}$ & $\mathbf{1 4 , 2} \%$ \\
\hline & Jumlah & $\mathbf{3 5}$ & $\mathbf{1 0 0 \%}$ \\
\hline
\end{tabular}

Sumber : Akademi Komunitas Negeri Jembrana Tahun 2018

Berdasarkan tabel 1.1, jumlah pengajar sebanyak 35 orang, diantaranya karyawan dengan tingkat pendidikan Strata 2 sebanyak 5 orang,
Strata 1 sebanyak 10 orang, Diploma 10 orang dan SLTA 10 Orang. Hal dapat mempengaruhi tingkat komunikasi antar pengajar satu dengan yang lain perlu diaktifkan secara regular guna menunjang pertumbuhan peminat dari siswa SLTA yang berkeinginan masuk di Prodi Diluar Domisili (PDD) Jembrana Politeknik Negeri Bali Rintisan Akademi Komunitas Negeri Jembrana

Berdasarkan Tabel 1.2 dapat dilihat bahwa Prodi Diluar Domisili (PDD) Jembrana Politeknik Negeri Bali Rintisan Akademi Komunitas Negeri Jembrana memiliki Mahasiswa dalam lima tahun terakhir dan tiga konsentrasi yaitu Kantor Depan (Front Office), Tata Graha (Food and Beverage Service), Tata Hidangan (Housekeeping) selalu meningakat rerata $45 \%$ dari yang mendaftar dan yang diterima. Berikut dapat dijelaskan jumlah Mahasiswa Prodi Diluar Domisili (PDD) Jembrana Politeknik Negeri Bali - Rintisan Akademi Komunitas Negeri Jembrana pada tahun 2018 pada tabel 1.2 sebagai berikut:

Tabel 1.2

Prodi Diluar Domisili (PDD) Jembrana Politeknik Negeri Bali - Rintisan Akademi Komunitas Negeri Jembrana

Tahun 2018

\begin{tabular}{|c|c|c|c|c|l|}
\hline Program Studi D1 Perhotelan & $\mathbf{2 0 1 4}$ & $\mathbf{2 0 1 5}$ & $\mathbf{2 0 1 6}$ & $\mathbf{2 0 1 7}$ & $\mathbf{2 0 1 8}$ \\
\hline$(1)$ & $\mathbf{( 2 )}$ & $\mathbf{( 3 )}$ & $\mathbf{( 4 )}$ & $\mathbf{( 5 )}$ & $\mathbf{( 6 )}$ \\
\hline Kosentrasi: Kantor Depan & & & & & \\
\hline Pendaftar & $\mathbf{5 0}$ & $\mathbf{5 6}$ & $\mathbf{2 7}$ & $\mathbf{4 1}$ & $\mathbf{2 9}$ \\
\hline Diterima & $\mathbf{2 2}$ & $\mathbf{2 1}$ & $\mathbf{2 2}$ & $\mathbf{2 0}$ & $\mathbf{1 6}$ \\
\hline Lulus & $\mathbf{2 0}$ & $\mathbf{2 0}$ & $\mathbf{1 6}$ & $\mathbf{1 7}$ & Belum Kelulusan \\
\hline Kosentrasi: Tata Hidangan & & & & & \\
\hline Pendaftar & $\mathbf{4 5}$ & $\mathbf{1 0 1}$ & $\mathbf{7 9}$ & $\mathbf{1 1 0}$ & $\mathbf{1 4 3}$ \\
\hline Diterima & $\mathbf{4 0}$ & $\mathbf{8 7}$ & $\mathbf{7 5}$ & $\mathbf{8 0}$ & $\mathbf{9 0}$ \\
\hline Lulus & $\mathbf{2 4}$ & $\mathbf{7 9}$ & $\mathbf{7 2}$ & $\mathbf{7 4}$ & Belum Kelulusan \\
\hline & & & & & \\
\hline
\end{tabular}

Ni Komang Ardety Pramesti Indahsari

IKetut Merta

I Made Anom Arya Pering 


\begin{tabular}{|c|c|c|l|l|l|}
\hline Kosentrasi: Tata Graha & & & & & \\
\hline Pendaftar & $\mathbf{5 2}$ & $\mathbf{8 6}$ & $\mathbf{1 0 9}$ & $\mathbf{1 0 8}$ & $\mathbf{1 1 1}$ \\
\hline Diterima & $\mathbf{4 7}$ & $\mathbf{6 8}$ & $\mathbf{9 8}$ & $\mathbf{7 6}$ & $\mathbf{7 5}$ \\
\hline Lulus & $\mathbf{4 0}$ & $\mathbf{6 7}$ & $\mathbf{8 3}$ & $\mathbf{6 8}$ & Belum Kelulusan \\
\hline Total & & & & & \\
\hline Pendaftar & $\mathbf{1 4 7}$ & $\mathbf{2 4 3}$ & $\mathbf{2 1 5}$ & $\mathbf{2 5 9}$ & $\mathbf{2 8 3}$ \\
\hline Diterima & $\mathbf{1 0 9}$ & $\mathbf{1 7 6}$ & $\mathbf{1 9 5}$ & $\mathbf{1 7 6}$ & $\mathbf{1 8 1}$ \\
\hline Lulus & $\mathbf{8 4}$ & $\mathbf{1 6 6}$ & $\mathbf{1 7 1}$ & $\mathbf{1 5 9}$ & Belum Kelulusan \\
\hline
\end{tabular}

Sumber : $\quad$ Prodi Diluar Domisili (PDD) Jembrana Politeknik Negeri Bali - Rintisan Akademi Komunitas Negeri Jembrana

Dalam organisasi komunikasi merupakan hal penting, karena tanpa adanya komunikasi organisasi tidak dapat bisa berjalan. Begitu pula dengan komunikasi, bila dalam organisasi komunikasinya kurang baik akan berdampak pada efektivitas organisasi. Komunikasi adalah sebuah proses dua arah yang memberikan kesempatan kepada orang yang berkomunikasi untuk merespons dan juga menyampaikan pesan-pesan, Denny dalam (Sinta, 2015 : 9). Dalam situasi tertentu pula komunikasi dimaksudkan untuk merubah sikap atau tingkah laku seseorang atau sejumlah orang sehingga ada efek tertentu yang diharapkan, dalam hal ini salah satunya adalah kepuasan kerja karyawan. Dapat dikatakan adanya komunikasi yang baik sangat menentukan kepuasan kerja karyawannya.

Komunikasi yang berjalan selama ini pada Prodi Diluar Domisili (PDD) Jembrana Politeknik Negeri Bali Rintisan Akademi Komunitas Negeri Jembrana meliputi komunikasi formal dan komunikasi informal. Komunikasi yang bersifat formal pada umumnya terjadi pada jam kerja seperti halnya dalam rapat dan pengarahan, sedangkan komunikasi yang bersifat informal biasanya terjadi diluar jam kerja seperti pada saat istirahat maupun saat pulang kerja. Adapun jenis pertemuan, frekuensi dan bentuk komunikasi formal pada Prodi Diluar Domisili (PDD) Jembrana Politeknik Negeri Bali - Rintisan Akademi Komunitas Negeri Jembrana Tahun 2018 dapat dilihat pada Tabel 1.3 berikut:

Tabel 1.3

Jenis Pertemuan, Frekuensi dan Bentuk Komunikasi Formal Pada Akademi Komunitas Negeri Jembrana

Tahun 2018

\begin{tabular}{|c|c|c|c|c|}
\hline No & Jenis Pertemuan & $\begin{array}{c}\text { Frekuensi } \\
\text { Pertemuan } \\
\end{array}$ & $\begin{array}{c}\text { Bentuk } \\
\text { Komunikasi } \\
\end{array}$ & Keterangan \\
\hline 1 & $\begin{array}{ll}\text { Pimpinan } & \text { dengan } \\
\text { kepala } & \text { bagian } \\
\text { (komunikasi } & \\
\text { vertikal) } & \end{array}$ & 12 kali per tahun & $\begin{array}{l}\text { a. Ceramah } \\
\text { b. Rapat berkala }\end{array}$ & $\begin{array}{l}\text { a. Meningkatkan } \\
\text { mutu pelayanan } \\
\text { perusahaan } \\
\text { b. Pemecahan } \\
\text { masalah yang }\end{array}$ \\
\hline
\end{tabular}

Ni Komang Ardety Pramesti Indahsari

IKetut Merta

I Made Anom Arya Pering 


\begin{tabular}{|c|l|c|c|c|}
\hline & & & & $\begin{array}{l}\text { timbul dalam } \\
\text { melakukan } \\
\text { pekerjaan }\end{array}$ \\
\hline 2 & $\begin{array}{l}\text { Kepala bagian } \\
\text { dengan karyawan } \\
\text { (komunikasi } \\
\text { horizontal) }\end{array}$ & 24 kali per tahun & $\begin{array}{l}\text { [1] Rapat berkala } \\
\text { [2] Rapat } \\
\text { kelompok }\end{array}$ & $\begin{array}{l}\text { a. Meningkatkan } \\
\text { mutu pelayanan } \\
\text { masing-masing } \\
\text { bagian } \\
\text { Meningkatkan } \\
\text { kinerja masing- } \\
\text { masing bagian }\end{array}$ \\
\hline 3 & $\begin{array}{l}\text { Kepala bagian } \\
\text { dengan } \\
\text { bagian(komunikasi } \\
\text { silang) }\end{array}$ & 4 kali per tahun & 1 Rapat berkala & $\begin{array}{l}\text { [1] Meningkatkan } \\
\text { komunikasi dan } \\
\text { kerja sama antar } \\
\text { bagian }\end{array}$ \\
\hline
\end{tabular}

Sumber : Prodi Diluar Domisili (PDD) Jembrana Politeknik Negeri Bali - Rintisan Akademi Komunitas Negeri Jembrana 
Dari Tabel 1.3 dapat dijelaskan bahwa komunikasi formal adalah proses komunikasi yang memanfaatkan saluran-saluran formal dalam struktur organisasi. Komunikasi formal yang terjadi pada Prodi Diluar Domisili (PDD) Jembrana Politeknik Negeri Bali Rintisan Akademi Komunitas Negeri Jembrana meliputi komunikasi vertikal, horizontal dan silang. Komunikasi vertikal adalah komunikasi dari pimpinan ke bawahan dan dari bawahan ke pimpinan secara timbal balik. Komunikasi horizontal adalah komunikasi secara mendatar, yaitu komunikasi antara karyawan dengan karyawan. Sedangkan komunikasi diagonal adalah komunikasi secara silang, yaitu komunikasi antara masing-masing kepala bagian. Sebaliknya komunikasi non formal adalah proses komunikasi yang dilakukan secara tidak resmi, artinya komunikasi terjadi antara orang yang ada dalam suatu organisasi, akan tetapi tidak direncanakan atau tidak ditentukan dalam struktur.

Beberapa masalah yang kerap terjadi di beberapa perusahaan / instansi berkaitan dengan komunikasi karyawan. Pimpinan tidak memberikan informasi tentang solusi yang harus dilakukan dalam mengatasi masalah pekerjaan sehingga karyawan maupun kelompok kerjanya kesulitan untuk mengambil keputusan. Selain itu, pimpinan kurang jelas dan tegas dalam mengarahkan karyawan untuk menyelesaikan tugas-tugas baru yang belum pernah dikerjakan.

Peran atau gaya dari pemimpin sangat perlu diperhatikan di dalam organisasi karena gaya kepemimpinan merupakan cermin bagi para karyawan, bagaimana pemimpin mempengaruhi, mengarahkan, mengontrol, mengawasi, serta memberikan perintah kepada karyawannya. Hal ini yang harus diperhatikan oleh setiap pemimpin, terkadang banyak pemimpin menyalahgunakan kepemimpinannya atau jabatannya untuk memberikan tugas dan perintah kepada karyawannya. Pemimpin yang baik akan menciptakan kinerja karyawan yang baik, sebaliknya pemimpin yang kurang baik akan menciptakan kinerja karyawan yang kurang baik pula.

Manajer yang efektif tentunya adalah mereka yang mau mendengarkan, memotivasi, dan memberikan dukungan bagi anak buahnya. Sementara itu nampaknya banyak melakukan hal-hal demikian yang lebih baik dari laki-laki Robbin (dalam Sudarmo: 5). Pendapat yang mengatakan bahwa memiliki perbedaan dalam gaya kepemimpinan didukung pula oleh hasil penelitian lainnya. Menurut Tannen (dalam Sudarmo: 6), laki-laki lebih menekankan pada status, sedangkan perempuan menekankan pada penciptaan hubungan.

Selain gaya kepemimpinan, komunikasi yang baik juga perlu diperhatikan agar karyawan dapat mengerti dan melaksanakan setiap pekerjaan yang diberikan dengan baik tanpa merasa diperintah, sehingga mampu memberikan hasil yang optimal. Komunikasi dapat mengandung arti luas daripada sekedar mengatakan atau menuliskan sesuatu. Komunikasi yang baik merupakan suatu motivasi. Kondisi seperti itu dapat mendorong perasaan

Ni Komang Ardety Pramesti Indahsari

IKetut Merta

I Made Anom Arya Pering 
untuk berpartisipasi akan lebih banyak menarik perhatian terhadap pekerjaan. Saling memberikan informasi tentang sesuatu yang menyangkut kepentingan bersama akan memberikan dukungan terhadap rasa saling membutuhkan. Berbagai pihak mendorong adanya kontak sehari-hari antara para manajer dan para non-manajer, untuk menjelaskan rencana-rencana dan kebijaksanaankebijaksanaan, memberitahukan perubahan-perubahan yang akan terjadi dikemudian hari, meminta gagasan-gagasan dan menanyakan pendapat mereka.

Berdasarkan uraian dari latar belakang masalah tersebut, maka penulis tertarik untuk melakukan penelitian yang berjudul "Pengaruh Gaya Kepemimpinan dan Komunikasi Terhadap Kinerja Organisasi Pada Prodi Diluar Domisili (PDD) Jembrana Politeknik Negeri Bali - Rintisan Akademi Komunitas Negeri Jembrana"

\subsection{Identifikasi Masalah}

Sesuai dengan latar belakang yang telah di sampaikan maka penulis dapat mengidentifikasi masalah yang terjadi di Prodi Diluar Domisili (PDD) Jembrana Politeknik Negeri Bali - Rintisan Akademi Komunitas Negeri Jembrana sebagai berikut:

1. Pemimpin kerap menyalahgunakan

kepemimpinannya atau jabatannya untuk memberi perintah kepada karyawan secara tidak baik, contohnya seperti memberi perintah dengan cara membentak atau menggunakan bahasa yang tidak sopan.
2. Kinerja karyawan dalam suatu organisasi tidak selalu baik apabila pimpinan tidak bisa memberikan solusi tentang apa yang harus dilakukan untuk mengatasi masalah, dan akan menyebabkan menurunnya kinerja karyawan.

3. Komunikasi dari atasan kepada bahawannya perlu diperhatikan agar karyawan dapat mengerti dan melaksanakan pekerjaannya dengan baik. Selain memerhatikan komunikasi yang terjadi antar atasan dengan bawahan, juga memerhatikan pentingnya komunikasi yang harus diterapkan sesama bawahan di Prodi Diluar Domisili (PDD) Jembrana Politeknik Negeri Bali. Diharapankan tercapainya kerjasama yang serasi dan harmonis.

Berdasarkan uraian latar belakang dan identifikasi masalah di atas, maka penulis berkeyakinan dan mendorong untuk melakukan penelitian. Dalam penelitian ini akan dilakukan pengujian guna untuk mengetahui ada tidaknya pengaruh signifikan antara Gaya Kepemimpinan dan Komunikasi secara simultan maupun parsial terhadap kinerja organisasi pada Prodi Diluar Domisili (PDD) Jembrana Politeknik Negeri Bali Rintisan Akademi Komunitas Negeri Jembrana.

\subsection{Pembahasan Masalah}

Adapun pembahasan masalah dalam penelitian ini adalah pengaruh Gaya Kepemimpinan dan komunikasi terhadap Kinerja Organiasi pada Prodi Diluar Domisili (PDD) Jembrana Politeknik Negeri Bali Rintisan Akademi Komunitas

Ni Komang Ardety Pramesti Indahsari

IKetut Merta

I Made Anom Arya Pering 
Negeri Jembrana. Dimana di harapkan Gaya Kepemimpinan dan komunikasi dapat memberi pengaruh terhadap kinerja organisasi. Ruang lingkup lokasi penelitian yang dipakai adalah Prodi Diluar Domisili (PDD) Jembrana Politeknik Negeri Bali Rintisan Akademi Komunitas Negeri Jembrana

\subsection{Rumusan Masalah Penelitian}

1. Bagaimanakah gaya kepemimpinan berpengaruh terhadap kinerja Organisasi pada Prodi Diluar Domisili (PDD) Jembrana Politeknik Negeri Bali - Rintisan Akademi Komunitas Negeri Jembrana?

2. Bagaimanakah komunikasi berpengaruh terhadap kinerja Organisasi pada Prodi Diluar Domisili (PDD) Jembrana Politeknik Negeri Bali - Rintisan Akademi Komunitas Negeri Jembrana ?

3. Bagaimanakah gaya kepemimpinan dan komunikasi berpengaruh terhadap kinerja pada Prodi Diluar Domisili (PDD) Jembrana Politeknik Negeri Bali - Rintisan Akademi Komunitas Negeri Jembrana

4. Untuk Mengetahui Variabel manakah yang memiliki pengaruh paling dominan antara gaya kepemimpinan dan komunikasi terhadap kinerja organisasi pada Prodi Diluar Domisili (PDD) Jembrana Politeknik Negeri
Bali - Rintisan Akademi

Komunitas Negeri Jembrana

\section{METODOLOGI PENELITIAN}

B. Operasional Variabel Penelitian

Menurut Sugiyono (2014)

Variabel penelitian adalah suatu atribut atau sifat atau nilai dari orang, obyek atau kegiatan yang mempunyai variasi tertentu yang ditetapkan oleh peneliti untuk dipelajari dan kemudian ditarik kesimpulannya. Menurut hubungan antara satu variabel dengan variabel yang lain, maka macam-macam variabel dalam penelitian dapat dibedakan menjadi Variabel : Independen, Dependen, Moderator, Intervening, Kontrol.

Menurut Jogiyanto dalam Kurniawan (2014) difinisi operasional variabel, variabelvariabel di dalam model harus didefinisikan agar jelas makna dan pengukurannya. Dua macam definisi yang diperlukan yaitu:

(1) Definisi naratif (narrative definition) yaitu definisi dalam bentuk kalimat untuk menjelaskan makna dan artinya.

(2) Definisi operasional (operational definition) yaitu definisi berupa cara mengukur variabel supaya dapat dioperasikan.

Dengan demikian operasional variabel dalam penelitian ini ditetapkan pada jenis variabel independen (bebas) yang menjadi sebab timbulnya variabel dependen (terikat). Sedangkan variabel dependen (terikat) adalah variabel yang dipengaruhi oleh variabel independen (bebas).

Ni Komang Ardety Pramesti Indahsari

IKetut Merta

I Made Anom Arya Pering 


\subsection{Identifikasi Variabel}

3.2.1 Gaya kepemimpinan X1)

Gaya kepemimpinan adalah suatu perpaduan sifat atau perilaku feminim dan maskulin yang khas yang dimiliki oleh untuk memimpin suatu organisasi dalam pencapaian tujuan yang telah ditentukan, dalam hal ini di Prodi Diluar Domisili (PDD) Jembrana Politeknik Negeri Bali - Rintisan Akademi Komunitas Negeri Jembrana. Perpaduan sifat feminim dan maskulin biasanya disebut dengan andogini. Adapun beberapa indikator yang digunakan untuk mengukur gaya kepemimpinan (Prihatinah, 2009:4) dengan indikator adalah sebagai berikut:

Variabel (X1) Gaya Kepemimpinan dengan indikator:

X1.1 Tingkat Kesabaran dan Rajin

X1.2 Dapat Dipercaya

X1.3 Motivasi Bagus, Pantang Menyerah, Kreatif

X1.4 Sadar Lingkungan, Menjaga Lingkungan

X1.5 Pengorganisasian yang Bagus

X1.6 Kepemimpinan yang Perduli

X1.7 Tidak Emosi

X1.8 Tidak Sebagai Karyawan, tapi Sebagai Pemimpin

\section{ii. Komunikasi (X2)}

Komunikasi adalah kegiatan yang dapat dilakukan oleh setiap orang dimanapun dia berada dan kapanpun, tinggal bagaimana setiap orang itu merespon setiap informasi yang disampaikan oleh lawan bicaranya menjadi satu kesamaan pemahaman. Berdasarkan data yang diperoleh di Prodi Diluar Domisili (PDD) Jembrana Politeknik Negeri Bali yang menjadi tolak ukur penilaiaan komunikasi adalah komunikator, informasi, perantara, penerima, umpan balik. Sumber : Variabel Independen (X2) Gorda (2004) dengan indikator sebagai berikut:

Variabel Independen

Komunikasi Organisasi dengan indikator :

X2. 1 Sebagai Komunikator

X2. 2 Menjadi Serangkaian Tanda yang Sistematis

X2. 3 Pengungkapan Pesan dalam Bentuk Lisan Maupun Tertulis

X2. 4 Sebagai Perantara

X2. 5 Menjadi Penerima dari Komunikasi

X2. 6 Sebagai Umpan Balik

iii. Kinerja Organisasi (Y)

Kinerja organisasi adalah hasil kerja yang dihasikan oleh karyawan sesuai dengan tugas dan tanggung jawabnya didalam organisasi dalam hal ini Prodi Diluar Domisili (PDD) Jembrana Politeknik Negeri Bali. Kriteria yang digunakan untuk mengukur kinerja karyawan adalah: kejujuran, kemampuan untuk melakukan kerjasama dengan team, kesetiaan, kuantitas dan kualitas pekerjaan, pengetahuan tentang tata tertib serta kehati-hatian dalam bekerja. Sumber variabel dependen (Y) menurut Husnan (2002) .dengan indikator sebagai berikut:

Variabel dependen (Y) Kinerja Organisasi dengan indikator :

Y 1 Kuantitas dan Kualitas Pekerjaan

Y 2 Kerjasama

Y 3 Kemampuan

Menyesuaikan Diri

Y 4 Kehati-hatian dalam Keselamatan Kerja

Ni Komang Ardety Pramesti Indahsari

IKetut Merta

I Made Anom Arya Pering 
Y 5 Pengetahuan Mengenai Jabatan

Y 6 Kerajinan

Y 7 Kesetiaan

Y 8 Dapat atau Tidaknya Diandalkan Dalam

Menjaga atau Memelihara Peralatan Kantor

Y 9 Inisiatif

\section{c. Instrumen Penelitian}

\section{[1] Uji Validitas}

Pengujian validitas bertujuan untuk memeriksa apakah isi kuesioner sudah cukup dipahami oleh responden, yang diindikasikan oleh kecilnya prosentase jawaban responden yang tidak terlalu menyimpang dengan rata-rata jawaban responden lain. Cara menguji validitas yaitu dengan mencari koefisien korelasi dari tiap responden yang menunjukkan kuat dan arah saling berhubungan antara variasi dua distributor skor.

$\begin{array}{lr}\quad \text { Uji } & \text { validitas } \\ \text { menggunakan } & \text { Bivariate } \\ \text { Correlation : } & \text { Correlation } \\ \text { Coefficients } & \text { Perason } \\ \text { menggunakan } & \text { Software }\end{array}$ SPSS. Cara menentukan validitas adalah dengan melihat hasil korelasi antara skor tiap butir dengan skor total yang merupakan penjumlahan tiap skor butir. Menurut Masrun seperti yang dikutip oleh Sugiyono (2014), syarat minimum untuk dapat memenuhi syarat validitas apabila korelasi antara skor butir dengan skor total adalah 0.3 ( $\mathrm{r}=0.3)$. Jadi kalau korelasi skor butir dengan skor totalnya kurang dari 0.3 maka angket tersebut dinyatakan tidak valid.

\section{[2] Uji Reliabilitas}

Pengujian reliabilitas bertujuan untuk mengetahui seberapa besar ukuran keandalan (reliable) suatu instrumen atau alat pengumpulan data. Keandalan tersebut dinyatakan pada responden yang berlainan, maka hasilnya tidak akan menyimpang terlalu jauh dari rata-rata jawaban responden untuk variabel tersebut.

Uji reabilitas adalah dengan Alpha Cronbach menggunakan Software Statistical Package for the Social Science (Software SPSS) versi 24 nilai $\alpha$ berkisar antara 0 sampai 1, semakin besar nilai yang diperoleh maka semakin reliabel variabel tersebut. Suatu variabel dikatakan reliabel jika memberikan nilai Alpha Cronbach> 0,60 (Nunnally, 1967).

Untuk mempermudah perhitungan data dalam analisis kuantitatif ini, penulis menggunakan alat bantu dengan program pengolah data statistik yaitu Software SPSS versi 24. Data ditampilkan dalam bentuk tabulasi untuk mempermudah pembacaan dan diberikan penjelasan secara deskriptif.

Ni Komang Ardety Pramesti Indahsari

IKetut Merta

I Made Anom Arya Pering 
Setelah data valid dan reliable, maka pengolahan data dilanjutkan dengan analisis-analisis lainnya, yaitu analisis korelasi, analisis regresi linier, analisis determinasi, uji F dan uji-t.

\section{[3] Korelasi Pearson Product Moment \\ Menurut Hasan Moment merupakan alat uji statistik yang digunakan untuk menguji hipotesis asosiatif (uji hubungan) dua variabel bila datanya bersekala interval atau rasio. Menurut Riduwan dan Sunarto (2009) kegunaan analisis ini untuk mengetahui derajat hubungan dan kontribusi variabel bebas (Independent). Analisis korelasi Person Product Moment dirumuskan:}

rxy

$=\frac{n\left(\sum X Y\right)-\left(\sum X\right) \cdot\left(\sum Y\right)}{\sqrt{\left\{n \cdot \sum X^{2}-\left(\sum X\right)^{2}\right\} \cdot\left\{n \cdot \sum Y^{2}-\left(\sum Y\right)^{2}\right\}}}$

Keterangan :

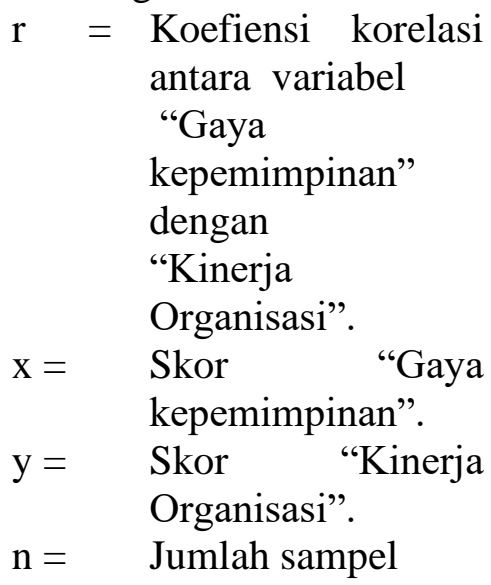

\begin{abstract}
Korelasi Person
Product

Moment

dilambangkan (r) dengan ketentuan nilai $\mathrm{r}$ tidak lebih dari harga $(-1 \leq \mathrm{r} \leq+1)$. Apabila nilai $\mathrm{r} \geq-1$ artinya korelasi aktif sempurna; $r=0$ artinya tidak ada korelasi ; dan $r \leq 1$ berarti korelasi sangat kuat.

Sedangkan arti harga $r$ akan dikonsultasikan dengan tabel inter- prestasi nilai $r$ yang dikemukakan oleh Riduwan dan Sunarto (2008) adalah sebagai berikut:
\end{abstract}

Tabel 3.2

Interpretasi Koefisien Korelasi Nilai $\mathbf{r}$

\begin{tabular}{|c|c|}
\hline $\begin{array}{c}\text { Interval } \\
\text { Koefisien }\end{array}$ & $\begin{array}{c}\text { Tingkat } \\
\text { Hubungan }\end{array}$ \\
\hline $0,800-1,000$ & Sangat Kuat \\
$0,600-0,799$ & Kuat \\
$0,400-0,599$ & Cukup Kuat \\
$0,200-0,399$ & Rendah \\
$0,000-0,199$ & Sangat Rendah \\
\hline
\end{tabular}
Sumber : Riduwan dan Sunarto (2008)

\section{.Teknik Analisis Data}

\section{Analisis Regresi Linier} Berganda

Analisis ini digunakan untuk mengetahui besarnya pengaruh perubahan Gaya Kepemimpinan dan Komunikasi secara simultan terhadap perubahan Kinerja Organiasi . Hasil analisis dinyatakan dalam bentuk persamaan garis linier berganda (Djarwanto dan Pangestu, 2000 : 209).

Ni Komang Ardety Pramesti Indahsari

IKetut Merta

I Made Anom Arya Pering 
Rumus :

$\grave{\mathbf{Y}}=\mathbf{a}+\mathbf{b}_{1} \mathbf{X}_{1}+\mathbf{b}_{2} \mathbf{X}_{2}$

Keterangan :

$\grave{Y}=$ Kinerja Orgnisasi

$\mathrm{a}=$ Nilai konstana

$\mathrm{b}_{1} \quad=$ Koefisien regresi

dari $\mathrm{X}_{1}$

$\mathrm{b}_{2}=$ Koefisien regresi

dari $\mathrm{X}_{2}$

$\mathrm{X}_{1} \quad=$

Gaya

Kepemimpinan

$\mathrm{X}_{2} \quad=$ Komunikasi

\section{Analisis Korelasi Berganda}

Analisis ini digunakan untuk mengetahui derajat hubungan secara simultan antara Gaya Kepemimpinan dan Komunikasi Terhadap Kinerja Organisasi (Djarwanto dan Pangestu, 2000 : 350) dengan rumus statistik :

$$
\mathrm{R}_{\mathbf{y}(\mathbf{1}, \mathbf{2})}=\frac{\sqrt{b 1 \Sigma X 1 Y+b 2 \Sigma X 2 Y}}{\Sigma Y 2}
$$

dalam analisis menggunakan alat bantu SPSS versi 24.

3. Analisis Determinasi

Analisis ini bertujuan untuk menyatakan besar kecilnya sumbangan variabel $\mathrm{X}$ terhadap $\mathrm{Y}$ yang dapat ditentukan dengan rumus koefisien determinasi: $\mathrm{D}=\mathrm{r}^{2}$ X $100 \%$

Dimana:

$\mathrm{D}=$ Nilai Koefisien Determinasi $\mathrm{r}=$ Nilai Koefisien Korelasi dalam analisis menggunakan alat bantu SPSS versi 24.

\section{Uji t (t-test)}

Uji t (t-test) digunakan

untuk mengetahui

signifikansi hubungan

hubungan antara variabel
Gaya Kepemimpinan dengan variabel Kinerja Organisasi , sehingga melalui uji $t$ ini dapat diketahui taraf signifikansinya.

Rumus uji signifikansi adalah sebagai berikut :

$\mathrm{t}=\frac{\mathrm{r} \sqrt{\mathrm{n}-2}}{\sqrt{1-\mathrm{r}^{2}}}$

dimana :

t t- hitung

$=$

r koefisien korelasi pearson

$=$ product moment

$\mathrm{n}$ jumlah sampel

$=$

\section{[4] Pengujian Hipotesis}

Uji hipotesis dalam penelitian ini dilakukan terhadap hipotesis statistik digunakan uji t dan uji F.

1. Uji T-Test

Pengujian uji $t$ digunakan untuk menguji signifikan antara hubungan variable gaya kepemimpinan dan komunikasi terhadap kinerja karyawan, apakah variabel gaya kepemimpinan dan komunikasi berpengaruh secara parsial terhadap variabel kinerja karyawan. Penyusunan hipotesis yang di uji, berupa hipotesis nol $\left(\mathrm{H}_{0}\right)$, dan hipotesis alternatif $\left(\mathrm{H}_{\mathrm{a}}\right)$. Tingkat kepercayaan yang digunakan atau taraf signifikan adalah $5 \%$ $(0,05)$ dengan formulasi

Ni Komang Ardety Pramesti Indahsari

IKetut Merta

I Made Anom Arya Pering 
dari Rangkuty (1997:33) sebagai berikut:

$$
\overline{\mathrm{t}=} b_{1}
$$

Keterangan :

$\mathrm{t}=$ Nilai $\mathrm{t}$ hitung

$b_{1}=$ Koefesien regresi

$S E b_{1}=$ Standar error

koefesien regresi

Hasil dari pengujian dengan menggunakan uji $t$ adalah:

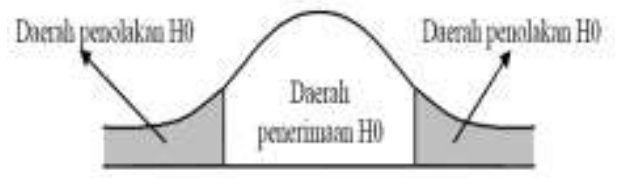

Gambar 3.1

Kurva Daerah Penerimaan dan Penolakan HO

berikut:

Dengan kriteria sebagai

[1]Jika t hitung > t tabel, maka H0, ditolak dan Ha diterima. Berarti masing-masing variabel bebas secara individu mempunyai pengaruh yang signifikan terhadap variabel terikat.

[2]Jika $\mathrm{t}$ hitung < t tabel, maka H0 diterima dan Ha ditolak. Berarti masing-masing variabel bebas secara individu tidak mempunyai pengaruh yang signifikan terhadap variabel terikat.

\section{Uji F-Test}

Pengujian ini dilakukan untuk mengetahui apakah semua variabel independen secara simultan (bersama-sama) berpengaruh terhadap variabel dependen. Uji F merupakan pengujian signifikan yang digunakan untuk mengetahui berapa besarnya pengaruh variabel independen (bebas) yaitu Gaya Kepemimpinan (X1) dan Komunikasi (X2) terhadap variabel dependen (terikat) yaitu Kinerja Karyawan. Pengujian ini dengan taraf signifikansi 5\% $(0,05)$ dengan formulasi sebagai berikut (Rangkuty, 1997:27) :

$$
F=\frac{R^{2} / k}{\left(1-R^{2}\right) /(n-k-}
$$

1)

Keterangan :

$\mathrm{F}=$ Nilai $\mathrm{F}$ hitung

$\mathrm{R}_{2}=$ Koefisien

determinasi ganda

$\mathrm{k}=$ Jumlah variabel

independen

$\mathrm{n}=$ Jumlah sampel

Hasil dari pengujian dengan menggunakan uji $\mathrm{F}$ adalah :

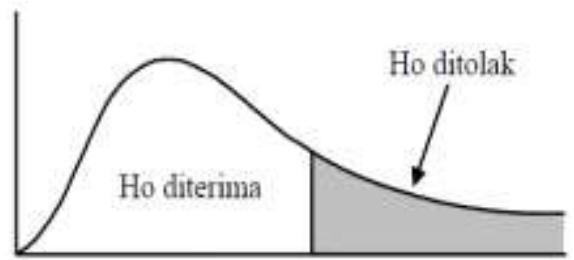

Gambar 3.2

Kurva HO diterima / ditolak

Dengan kaidah pengambilan keputusan sebagai berikut :

a. Jika probabilitas $<0,05$ maka $\mathrm{H} 0$ ditolak, berarti masing-masing variabel bebas secara bersamasama mempunyai pengaruh yang positif terhadap variabel terikat.

b. Jika probabilitas > 0,05, maka $\mathrm{H} 0$ diterima, berarti masing-masing variabel bebas secara bersamasama tidak mempunyai pengaruh

Ni Komang Ardety Pramesti Indahsari

IKetut Merta

I Made Anom Arya Pering 
yang positif terhadap variabel terikat.

\subsection{Hasil Analisis Kualitatif}

\subsubsection{Deskripsi Variabel Penelitian}

Berdasarkan hasil tabulasi data yang diperoleh melalui kuesioner yang telah disebarkan kepada 35 orang responden yang merupakan Dosen dan Karyawan Pada Pada Prodi Diluar Domisili (PDD) Jembrana Politeknik Negeri Bali dengan variabel Gaya Kepemimpinan (X1) Dan Komunikasi (X2) dan Kinerja Organisasi(Y)

\subsubsection{Deskripsi Data Penelitian}

\subsubsection{Karakteristik} Responden Berdasarkan Jenis Kelamin

Adapun karakteristik responden berdasarkan jenis kelamin dapat dilihat pada tabel berikut ini.

\section{Tabel 4.1}

Karakteristik Responden Berdasarkan Jenis Kelamin

\begin{tabular}{|c|c|c|c|}
\hline $\begin{array}{c}\text { No } \\
.\end{array}$ & $\begin{array}{c}\text { Jenis } \\
\text { Kelamin }\end{array}$ & $\begin{array}{c}\text { Jumla } \\
\text { h }\end{array}$ & $\begin{array}{c}\text { Prosentas } \\
\text { e }\end{array}$ \\
\hline 1 & Laki-Laki & $\mathbf{2 5}$ & $\mathbf{6 5 \%}$ \\
\hline 2 & $\begin{array}{c}\text { Perempua } \\
\text { n }\end{array}$ & $\mathbf{1 0}$ & $\mathbf{3 5 \%}$ \\
\hline 3 & Jumlah & $\mathbf{3 5}$ & $\mathbf{1 0 0 \%}$ \\
\hline
\end{tabular}

Sumber : data primer diolah, 2019

Pada Tabel 4.1 dapat dilihat jumlah responden laki - laki sebanyak 25 orang dengan presentase sebesar $65 \%$ dan perempuan sebanyak 10 orang dengan presentase sebesar $35 \%$.

\subsubsection{Karakteristik Responen Berdasarkan Usia}

Adapun karakteristik responden berdasarkan tingkat Usia dapat dilihat pada tabel berikut ini

Tabel 4.2

Karakteristik Responden Berdasarkan Usia

\begin{tabular}{|c|c|c|c|}
\hline No. & $\begin{array}{c}\text { Usia } \\
\text { (Tahun } \\
\text { ) }\end{array}$ & Jumlah & Pr29oentase \\
\hline 1 & $21-30$ & 10 & $29 \%$ \\
\hline 2 & $31-40$ & 15 & $42 \%$ \\
\hline 3 & $>40$ & 10 & $29 \%$ \\
\hline & Jumlah & 35 & $100 \%$ \\
\hline
\end{tabular}
2019

Pada Tabel 4.2 dapat dideskripsikan bahwa responden yang berusia dibawah 21-30 tahun berjumlah 10 orang (29\%), pada usia 31-40 tahun jumlah responden berjumlah 15 orang (42\%), pada usia 40 tahun berjumlah 10 orang (29\%),

\subsubsection{Karakteristik Responden Berdasarkan Tingkat Pendidikan}

Adapun karakteristik responden berdasarkan tingkat pendidikan dapat dilihat pada tabel berikut ini.

Tabel 4. 3

Karakteristik Responden Berdasarkan Pendidikan

\begin{tabular}{|c|c|c|c|}
\hline No. & $\begin{array}{c}\text { Pekerjaa } \\
\text { n }\end{array}$ & $\begin{array}{c}\text { Jumla } \\
\text { h }\end{array}$ & $\begin{array}{c}\text { Prosentas } \\
\text { e }\end{array}$ \\
\hline 1 & SLTA & 10 & $28,6 \%$ \\
\hline 2 & DI & 10 & $28,6 \%$ \\
\hline 3 & S1 & 10 & $28,6 \%$ \\
\hline 4 & S2 & 5 & $14.2 \%$ \\
\hline & Jumlah & 35 & $100 \%$ \\
\hline
\end{tabular}

Ni Komang Ardety Pramesti Indahsari 
Sumber : data primer diolah, 2018

\section{Dari Tabel 4.3 Jumlah} Responden Berdasarkan Tingkat Pendidikan adalah SLTA sebanyak 10 orang $(28,6 \%)$, Pendidikan Diploman III sebnayak 10 orang $(28,6$ $\%)$ dan Strata 1 (S1) sebanyak 10 orang $(28,6 \%)$. Serta (S2) Pascasarjana sebanyak 5 orang $(14,2$ $\%)$

\subsection{Identifikasi Variabel}

Berdasarkan hasil tabulasi data yang diperoleh melalui kuesioner yang telah disebarkan kepada 35 orang responden yang merupakan Dosen dan Karyawan Pada Prodi Diluar Domisili (PDD) Jembrana Politeknik Negeri Bali dengan variabel:

1. Gaya Kepemimpinan (X1)

2. Komunikasi (X2) dan

3. Kinerja Organisasi (Y)

Ketiga variabel penelitian tersebut menggambarkan tujuan dari suatu perusahaan untuk digabungkan dalam kesempatan Gaya Kepemimpian, Komunikasi guna menumbuhkan Kinerja Organisasi serta tingkat responsif perusahaan terhadap Kinerja Organisasi . Gaya Kepemimpnan dan Komunikasi menjadi pusat perhatian manajemen dalam membangun strategi meningkatkan Kinerja Organisasi , membangun keunggulan bersaing, mengembangkan inovasi, mengidentifitasi kebutuhan dan keinginan karyawan dan memonitor kinerja, melalui orientasi Kinerja Organisasi

\subsubsection{Instrumen Penelitian 1. Uji Validitas}

Ni Komang Ardety Pramesti Indahsari

IKetut Merta

I Made Anom Arya Pering
Uji validitas menggunakan Bivariate Correlation : Correlation Coefficients Person menggunakan Software SPSS Versi 24. Cara menentukan validitas adalah dengan melihat hasil korelasi antara skor tiap butir dengan skor total yang merupakan penjumlahan tiap skor butir. Menurut Masrun seperti yang dikutip oleh Sugiyono (2014), syarat minimum untuk dapat memenuhi syarat validitas apabila korelasi antara skor butir dengan skor total adalah $0.3(\mathrm{r}=$ 0.3 ). Jadi kalau korelasi skor butir dengan skor totalnya kurang dari 0.3 maka angket tersebut dinyatakan tidak valid.

Dari hasil Item-Total Statistics Cronbach's Alpha moment Pearson, diketahui bahwa semua item pertanyaan pada kuesioner yang telah dijawab oleh responden, sehingga dapat dikatakan semua item pertanyaan adalah valid. Dengan Variabel independen pada penelitian ini adalah Gaya Kepempinan (X1), Komunikasi (X2), Kinerja Organisasi (Y). Selanjutnya koefisien korelasi yang diperoleh $r$ tabel masih harus diuji signifikansinya dengan membandingkan dengan tabel r. Butir pertanyaan dikatakan valid jika nilai $r$ hitung $>\mathrm{r}$ tabel atau nilai $\mathrm{p}<0,05$ dengan uji validitas adalah suatu dapat dipercaya kebenarannya sesuai dengan kenyataan.

\section{Uji Reliability Statistics}

Pengujian reliabilitas bertujuan untuk mengetahui seberapa besar ukuran keandalan (reliable) suatu instrumen atau alat pengumpulan data. Keandalan tersebut dinyatakan pada responden 
yang berlainan, maka hasilnya tidak akan menyimpang terlalu jauh dari rata-rata jawaban responden untuk variabel tersebut.

Uji reabilitas adalah dengan Alpha Cronbach menggunakan Software Statistical Package for the Social Science (Software SPSS) versi 24 nilai $\alpha$ berkisar antara 0 sampai 1 , semakin besar nilai yang diperoleh maka semakin reliabel variabel tersebut. Suatu variabel dikatakan reliabel jika memberikan nilai Alpha Cronbach > 0,60 (Nunnally, 1967). Sesuai tabel 4.5 dibawah ini.

Tabel 4.5

Reliability

\begin{tabular}{|c|c|c|}
\hline & \multicolumn{2}{|l|}{ Reliability Statistics } \\
\hline Variabel & $\begin{array}{l}\text { Cronbach's } \\
\text { Alpha }\end{array}$ & Reabel \\
\hline $\begin{array}{c}\text { Gaya Kepemimpinan } \\
\text { (X1) }\end{array}$ & .948 & 25 \\
\hline Komunikasi ( X2) & & Reliabel \\
\hline $\begin{array}{c}\text { Kinerja Oganisasi } \\
\text { (Y) }\end{array}$ & & Reliabel \\
\hline
\end{tabular}

\subsection{HASIL PENELITIAN DAN PEMBAHASAN}

Berdasarkan Latar belakang, Landasan Teori dan kerangka pemikiran dan kerangka konsep serta metode penelitian dapat dianalisis data-data untuk menjawab hipotesis.

\subsubsection{Hasil Penelitian}

\subsubsection{Teknik Analisis Data}

\subsubsection{Uji Asumsi Klasik}

$$
\text { Uji asumsi }
$$

klasik bertujuan untuk menguji apakah variabel yang dioperasikan bebas dari adanya penyimpangan. Uji asumsi klasik yang dilakukan dalam penelitian ini terdiri dari uji normalitas, uji multikolinieritas, dan uji heteroskedastisitas.
Model regresi yang baik adalah model regresi yang terbebas dari masalah multikolinieritas, heteroskedastisitas, serta masalah normalitas data.

\section{a. Uji Normalitas}

Uji Normalitas dilakukan untuk menguji apakah pada residual dari model regresi yang telah dibuat berdistribusi normal atau tidak (Suyana, 2009: 89). Model regresi yang baik merupakan model yang memiliki distribusi residual yang normal atau mendekati normal. Metode yang digunakan adalah dengan menggunakan statistik Kolmogorov-Smirnov untuk mengetahui signifikasi data yang berdistribusi normal. Kriteria yang digunakan uji ini adalah dengan membandingkan antara tingkat signifikasi yang didapat dengan tingkat alpha yang digunakan yaitu 5\% $(0,05)$, dimana data tersebut dikatakan berdistribusi normal bila sig > alpha (Suyana, 2009: 89). Pada Uji Normalitas Regresi penyebaran distribusi residual pada tingkat garis lurus maka dinyatakan normal

\section{Uji Multikolinieritas}

Uji Multikolinieritas bertujuan untuk menguji apakah pada model regresi ditemukan adanya korelasi antar variabel bebas (Ghozali, 2009:95). Model regresi yang baik seharusnya tidak terjadi korelasi diantara variable bebas,artinya bebas dari gejala multikolinier (Suyana, 2009:94).

Jika suatu model regresi mengandung gejala multikolinieritas dipaksa untuk

Ni Komang Ardety Pramesti Indahsari

IKetut Merta

I Made Anom Arya Pering 
digunakan, maka akan memberikan hasil prediksi yang menyimpang. Untuk mendeteksi ada atau tidaknya korelasi antar variabel bebas dapat dilihat dari nilai tolerance diatas 0,1 dan nilai Variance Inflation Factor (VIF) dibawah 10 yang berarti tidak terdapat gejala multikolinieritas. Pada Tabel 4.7 mengandung penyebaran residual merata sehinga model regresi dikatakan multikolinieritas

Tabel 4.7

Multikolinieritas

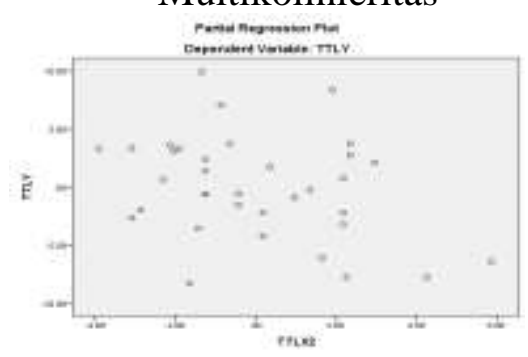

\subsection{Uji Heteroskedastisitas}

Uji Heteroskedastisitas dengan tujuan mengkaji apakah dalam model regresi ditemukan ketidaksamaan varian dari residual atau pengamatan kepengamatan lain. Model regresi yang baik adalah yang tidak mengandung gejala heteroskedastisitas atau mempunyai varians yang homogen (Suyana, 2009: 94). Uji yang digunakan adalah Glejser. Jika tingkat signifikansi berada di atas 0,05 maka model regresi ini bebas dari masalah heteroskedastisitas. Pada Tabel 4.8 Model regresi yang baik adalah yang tidak mengandung gejala heteroskedastisitas atau mempunyai varians yang homogeny sehingga dikatakan Heteroskedastisitas

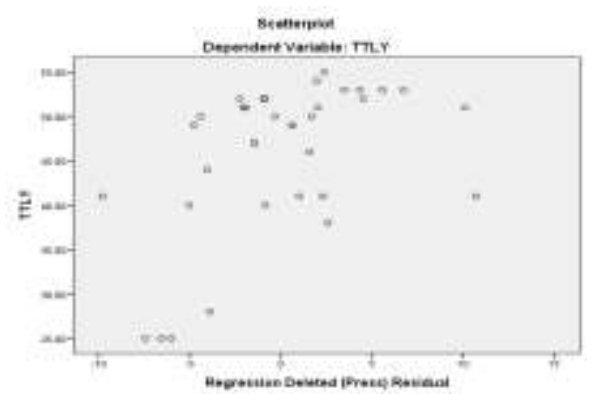

\subsubsection{Analisis Regresi Linier Berganda}

Berdasarkan Tabel 4. 9 di bawah dapat disimpulkan bahwa variabel Kinerja Organisasi (Y) dipengaruhi oleh variabel yang digunakan dalam penelitian yaitu Gaya kepempinan (X1) dan Komunikasi (X2), sehingga terbentuk persamaan regresi bergada berikut ini: $\mathrm{Y}=\mathrm{a}+\mathrm{b} 1 \mathrm{X} 1-\mathrm{b} 2 \mathrm{X} 2$

diperoleh hasil $\mathrm{Y}=-2.344+1.894-$ 0.622

Dari persamaan regresi berganda tersebut dijelaskan sebagai berikut: (Konstanta) a $=-2.344$; artinya apabila variabel Gaya Kepemipinan (X1), dan Variabel Komunikasi (X2) diasumsikan tidak memiliki pengaruh sama sekali $(=0)$ maka Kinerja Organisasi adalah sebesar -2.344 .

Variabel

Gaya

Kepemimpinan (X1) dengan memiliki koefisien sebesar 1.894 artinya Variabel Komunikasi (X2) memiliki koefisien sebesar -0.622 artinya Rendah

Tabel 4.9

Hasil Analisis Persamaan Regresi Linier Berganda

Ni Komang Ardety Pramesti Indahsari

IKetut Merta

I Made Anom Arya Pering 


\begin{tabular}{|c|c|c|c|c|c|}
\hline \multirow[t]{2}{*}{ Model } & \multicolumn{2}{|c|}{$\begin{array}{l}\text { Unstandardized } \\
\text { Coefficients }\end{array}$} & \multirow{2}{*}{\begin{tabular}{|c}
$\begin{array}{c}\text { Standardized } \\
\text { Coefficients }\end{array}$ \\
Beta \\
\end{tabular}} & \multirow[t]{2}{*}{$\mathrm{t}$} & \multirow[t]{2}{*}{ Sig. } \\
\hline & B & $\begin{array}{l}\text { Std. } \\
\text { Error }\end{array}$ & & & \\
\hline (Constant) & -2.344 & 6.889 & & -.340 & .736 \\
\hline $\begin{array}{l}\text { Gaya } \\
\text { Kepemimpinan }\end{array}$ & 1.894 & .206 & .988 & 9.185 & .000 \\
\hline Komunkasi & -.622 & .323 & -.207 & $\begin{array}{r}- \\
1.922\end{array}$ & .064 \\
\hline
\end{tabular}

a. Dependent Variable: Kinerja Organisasi

\subsubsection{Analisis Berganda}

Korelasi variabel Gaya Kepemimpinan dan Variabel Komunikasi terhadap variabel Kinerja Organisasi sebagai berikut :

a. Variabel Gaya Kepemimpinan (X1) berpengaruh terhadap Kinerja Organisasi sebesar 0,613 artinya faktor gaya kepemipinan berpengaruh "kuat" mempengaruhi kinerja Organisasi Pada Prodi Diluar Domisili (PDD) Jembrana Politeknik Negeri Bali

b. Variabel Komunikasi berpengaruh terhadap Kierja
Organisasi sebesar 0,861 berati Komunkasi "sangat kuat" mempengarui Kierja Organisasi Pada Prodi Diluar Domisili (PDD) Jembrana Politeknik Negeri Bali

c. Variabel antara Gaya Kepemipian (X1) dan Komunkasi (X2) berpengaruh sebasar 0,613 dan 0.861 dengan rerata 1 berarti Gaya Kepemimpinan dan Komunkasi sangat kuat mempengaruhi Kierja Organisasi Pada Prodi Diluar Domisili (PDD) Jembrana Politeknik Negeri Bali

Tabel 4.6

Korelasi Hubungan Antar Variabel Correlations

\begin{tabular}{|c|c|c|c|c|}
\hline & & $\begin{array}{c}\text { Gaya } \\
\text { Kepemimpinan }\end{array}$ & Komunikasi & $\begin{array}{c}\text { Kinerja } \\
\text { Organisasi }\end{array}$ \\
\hline Gaya & $\begin{array}{l}\text { Pearson } \\
\text { Correlation }\end{array}$ & 1 & $.613^{* *}$ & \\
\hline Kepemimpinan & Sig. (2-tailed) & & .000 & .000 \\
\hline & $\mathrm{N}$ & 35 & 35 & 35 \\
\hline Komunikasi & $\begin{array}{l}\text { Pearson } \\
\text { Correlation }\end{array}$ & $.613^{* *}$ & 1 & $.399^{*}$ \\
\hline
\end{tabular}

Ni Komang Ardety Pramesti Indahsari

IKetut Merta

I Made Anom Arya Pering 


\begin{tabular}{|c|c|c|c|c|}
\hline & $\begin{array}{l}\text { Sig. (2-tailed) } \\
\mathrm{N}\end{array}$ & $\begin{array}{r}.000 \\
35\end{array}$ & 35 & $\begin{array}{r}.018 \\
35\end{array}$ \\
\hline Kinerja Organisasi & $\begin{array}{l}\text { Pearson } \\
\text { Correlation }\end{array}$ & $.861^{* *}$ & $.399^{*}$ & 1 \\
\hline & $\begin{array}{l}\text { Sig. (2-tailed) } \\
\mathrm{N}\end{array}$ & $\begin{array}{r}.000 \\
35\end{array}$ & $\begin{array}{r}.018 \\
35\end{array}$ & 35 \\
\hline
\end{tabular}

**. Correlation is significant at the 0.01 level (2-tailed).

*. Correlation is significant at the 0.05 level (2-tailed).

Ni Komang Ardety Pramesti Indahsari

IKetut Merta

I Made Anom Arya Pering 


\subsubsection{Analisis Determinasi}

Berdasarkan Tabel 4.10 diawah dapat diketahui bahwa koefisien determinasi (adjusted R) yang diperoleh sebesar $75.4 \% \mathrm{Hal}$ ini menunjukkan bahwa Gaya Kepempinan dan Komunikasi terhadap Kinerja organisasi sebesar $75.4 \%$ Sedangkan sisanya sebesar $24.6 \%$ Gaya Kepempinan dan Komunikasi dipengaruhi oleh variabel-variabel lainnya yang tidak diteliti dalam penelitian ini.

Tabel 4.10

Hasil Analisis Determinasi

Model Summary

\begin{tabular}{|l|r|r|r|c|}
\hline $\begin{array}{l}\text { Mode } \\
1\end{array}$ & $\mathrm{R}$ & $\begin{array}{c}\mathrm{R} \\
\text { Squar } \\
\mathrm{e}\end{array}$ & $\begin{array}{c}\text { Adjuste } \\
\mathrm{d} \mathrm{R} \\
\text { Square }\end{array}$ & $\begin{array}{c}\text { Std. } \\
\text { Error of } \\
\text { the } \\
\text { Estimat } \\
\mathrm{e}\end{array}$ \\
\hline 1 & $\begin{array}{r}.877 \\
\mathrm{a}\end{array}$ & .769 & .754 & 4.289 \\
\hline
\end{tabular}
a. Predictors: (Constant), J_KOM,
J_KEPIM

\subsubsection{Pengujian Hipotesis}

Uji hipotesis dalam penelitian ini dilakukan terhadap hipotesis statistik digunakan uji $t$ dan uji $F$.

\subsubsection{Uji T-Test}

Hasil Uji t (t-test) berdasarkan Tabel 4.8 dibawah ini=Berikut ini dijelaskan hasil perhitungan uji t pada masing-masing variablel:

1. Hasil uji t pada variabel Gaya Kepemimpian menghasilkan: $\mathrm{t}$ hitung sebesar 9.185 dan signifikansi sebesar 0,000. $\mathrm{t}$ hitung $9.185>\mathrm{t}$ tabel yang nilainya 1.69 maka dapat diketahui bahwa hipotesis yang menyatakan Gaya Kepemimpinan "berpengaruh positif signifikan" terhadap Kinerja Organisasi Pada Prodi Diluar Domisili (PDD) Jembrana Politeknik Negeri Bali

2. Variabel Komunikasi menghasilkan t hitung sebesar 1.922 dan signifikansi sebesar 0.064. $\mathrm{t}$ hitung $-1.922>\mathrm{t}$ tabel yang nilainya 1,69 maka dapat diketahui bahwa hipotesis yang menyatakan Komunikasi berpengaruh "negative tidak signifikan" terhadap Kinerja Organisasi Pada Prodi Diluar Domisili (PDD) Jembrana Politeknik Negeri Bali.

Tabel 4.8

Uji T/Koefisien

Coefficients $^{\mathrm{a}}$

\begin{tabular}{|ll|r|r|r|r|r|}
\hline \multirow{2}{*}{ Model } & \multicolumn{2}{|c|}{$\begin{array}{c}\text { Unstandardized } \\
\text { Coefficients }\end{array}$} & $\begin{array}{l}\text { Standardized } \\
\text { Coefficients }\end{array}$ & \multirow{2}{*}{ Sig. } \\
\cline { 2 - 5 } & \multicolumn{1}{|c|}{$\mathrm{B}$} & \multicolumn{1}{c|}{ Std. Error } & \multicolumn{1}{c|}{ Beta } & & \\
\hline \multirow{2}{*}{$1 \quad$ (Constant) } & -2.344 & 6.889 & & -.340 & .736 \\
\cline { 2 - 6 } & Gaya Kepemimpinan & 1.894 & .206 & .988 & 9.185 & .000 \\
& Komunikasi & -.622 & .323 & -.207 & -1.922 & .064 \\
\hline
\end{tabular}

a. Dependent Variable: Kinerja Organisasi

Ni Komang Ardety Pramesti Indahsari

IKetut Merta

I Made Anom Arya Pering 


\subsubsection{Uji F-Test}

Berdasarkan tabel 4 di bawah ini hasil perhitungan statistik menunjukkan nilai $\mathrm{F}$ hitung $=53.194>\mathrm{F}$ table $(2.02)=$ 51.174 dan signifikansi sebesar $0,000<$ 0,05. Maka Variabel Gaya Kepemimpinan dan Variabel Komunikasi secara simultan atau bersama-sama berpengaruh signifikan terhadap Variabel Kinerja Organisasi.

\section{Tabel 4.7}

Uji F/Anova

ANOVA $^{\mathrm{a}}$

\begin{tabular}{|l|r|r|c|c|c|}
\hline Model & $\begin{array}{c}\text { Sum of } \\
\text { Square } \\
\mathrm{s}\end{array}$ & $\mathrm{df}$ & $\begin{array}{c}\text { Mean } \\
\text { Square }\end{array}$ & $\mathrm{F}$ & Sig. \\
\hline $\begin{array}{l}\text { Regressi } \\
\text { on }\end{array}$ & $\begin{array}{r}1956.9 \\
25\end{array}$ & 2 & 978.462 & 53.194 & $.000^{\mathrm{b}}$ \\
1 Residual & $\begin{array}{r}588.61 \\
8\end{array}$ & 32 & 18.394 & & \\
$\quad$ Total & $\begin{array}{r}2545.5 \\
43\end{array}$ & 34 & & & \\
\hline
\end{tabular}

a. Dependent Variable: Gaya Kepemimpinan

b. Predictors: (Constant), Komunikasi, Kineja Organisasi

\subsubsection{Pembahasan}

Pada hasil penelitian, analisis dan pembahasan mengenai masalah Pengaruh antara variabel independen (Gaya Kepemimpinan, Komunikasi) dan dependen (Kinerja Organisasi ) dapat dijelaskan sebagai berikut:

1. Variabel Gaya Kepemimpinan (X1) berkorelasi terhadap Kinerja Organisasi sebesar 0,613 artinya faktor gaya kepemipinan kuat mempengaruhi kinerja Organisasi. Berdasakan Hasil uji t pada variabel Gaya Kepemimpian menghasilkan: $\mathrm{t}$ hitung sebesar 9.185 dan signifikansi sebesar 0,000. t hitung 9.185 > t tabel yang nilainya 1.69 maka dapat diketahui bahwa hipotesis yang menyatakan Gaya Kepemimpinan secara farsial berpengaruh "positif signifikan" terhadap Kinerja Organisasi Pada Prodi Diluar Domisili (PDD) Jembrana Politeknik Negeri Bali

2. Variabel Komunikasi (X2) berkorelasi terhadap Kierja Organisasi sebesar 0,861 berati Komunkasi "sangat kuat" mempengaruhi Kierja Organisasi. Komunikasi menghasilkan t hitung sebesar -1.922 dan signifikansi sebesar 0.064. $\mathrm{t}$ hitung $-1.922>\mathrm{t}$ tabel yang nilainya 1,69 maka dapat diketahui bahwa hipotesis yang menyatakan Komunikasi secara farsial berpengaruh "negative tidak signifikan" terhadap Kinerja Organisasi Pada Prodi Diluar Domisili (PDD) Jembrana Politeknik Negeri Bali

3. Variabel antara Gaya Kepemipian (X1) dan Komunkasi (X2) dengan F - hitung 53.194 dan Signifikan 0,000 berarti secara simultan atau bersama-sama berpengaruh "positif signifikan" terhadap Kinerja Organisasi (Y) Organisasi Pada Prodi Diluar Domisili (PDD) Jembrana Politeknik Negeri Bali.

\section{a Kesimpulan:}

1. Gaya Kepemimpinan (X1) berkorelasi terhadap Kinerja Organisasi sebesar 0,861 artinya faktor gaya kepemipinan sangat mempengaruhi kinerja Organisasi. Berdasakan Hasil uji t pada variabel Gaya Kepemimpian menghasilkan: $\mathrm{t}$ hitung sebesar 9.185dan 
signifikansi sebesar 0,000. $\mathrm{t}$ hitung 9.185> t tabel yang nilainya 1.69 , maka dapat diketahui bahwa hipotesis yang menyatakan Gaya Kepemimpinan berpengaruh positif signifikan terhadap Kinerja Organisasi Pada Prodi Diluar Domisili (PDD) Jembrana Politeknik Negeri Bali

2. Variabel Komunikasi (X2) berkorelasi terhadap Kinerja Organisasi sebesar 0,399 berati Komunkasi cukup kuat mempengaruhi Kinerja Organisasi. Komunikasi menghasil $\mathrm{t}$ hitung sebesar -1.922 dan signifikansi sebesar 0.064. $\mathrm{t}$ hitung $-1.922>\mathrm{t}$ tabel yang nilainya 1,69 maka dapat diketahui bahwa hipotesis yang menyatakan Komunikasi berpengaruh negatif dan tidak signifikan terhadap Kinerja Organisasi Pada Prodi Diluar Domisili (PDD) Jembrana Politeknik Negeri Bali

3. Variabel antara Gaya Kepemipian (1) dan Komunkasi (X2) berkorelasi sebasar 0,399 dan 0.861 dengan rerata 1 berarti Gaya Kepemimpinan dan Komunkasi sangat kuat mempengaruhi Kinerja Organisasi. Hipotesi diterima dengan $\mathrm{F}$ hitung 53,194 dan sig 0,000, maka hipotesis yang menyatakan adanya pengaruh yang positif secara simular antara Gaya Kepemimpinan dan Komunikasi terhadap Kinerja Organisasi Pada Prodi Diluar Domisili (PDD) Jembrana Politeknik Negeri Bali

\section{Saran-Saran:}

1. Gaya Kempimpinan sangat kuat mempegaruhi kinerja oragniasi hal ini sangat tergantung pada karakter gaya kepemipinan serta kaderisasi kepemimpnan sagat dibutuhkan guna mempertahankan organisasi.

2. Komunikasi kuat dalam kinerja organisasi maka diperlukan komunikai yang baik dan benar guna menjaga harmonisasi organisai.

3. Gaya kepemimpinan dan Komunikasi sangat kuat dalam kinerja organisasi, Maka kaderisasi kepemimpinan dan Tata bahasa dalam komunikasi perlu ditingkatkan.

\section{DAFTAR PUSTAKA}

Ajeng Kartika, Sopranita. 2014. "Pengaruh Gaya Kepemimpinan Terhadap Kinerja Karyawan Dengan Motivasi Kerja Sebagai Variabel Moderating".Skripsi. Surakarta: Universitas Muhammadiyah Surakarta.

Al-Ahmadi, H. 2009.“Factors Affecting Performance of Hospital Nurses in Riyadh Region, Saudi Arabia".International Journal of Health Care Quality Assurance.Vol. 22, No. 1, pp. 4054

Armstrong, Michael. 2013. Manajemen Sumber Daya Manusia. Terjemahan oleh Sofyan Cikmat dan Haryanto.2013. Jakarta: PT Elex Media Komputindo.

Ghozali, Imam. 2001. Analisis Multivanate dengan program SPSS. Edisi ke 2. Universitas Diponegoro. 
Guritno, Bambang dan Waridin. 2005. Pengaruh Persepsi Karyawan Mengenai Perilaku Kepemimpinan, Kepuasan Kerja Dan Motivasi Terhadap Kinerja. JRBI. Vol 1. No. Hal:63-74.

Hadi, Syamsul. 2006. Metodeologi Penelitian Kuantitatif untuk Akuntansi \& Keuangan. Yogyakarta: Ekonisia.

Handoko, T. Hani. 2000. Organization Perusahaan Teori Struktur Dan Perilaku. Edisi 2. Yogyakarta: BPFE.

Mangkunegara, AA Anwar Prabu. 2005. Manajemen Sumber Daya Manusia Perusahaan. Bandung: PT Remaja Rosdakarya.

Mas'ud, Fuad (2004), Survai Diagnosis Organisasional (Konsep dan Aplikasi). Semarang: Badan Penerbit Universitas Diponegoro.

Nafisah, Durrotun. 2005. "Analisis Pengaruh Gaya Kepemimpinan Terhadap Kepuasan Kerja, Komitmen Organisasi dan Kinerja Karyawan". Skripsi Managemen. Fakultas Ekonomi Universitas Diponegoro 2005.

Rivai, Veithzal dan Basri. 2005. Performance Appraisal: Sistem Yang Tepat Untuk Menilai Kinerja Karyawan dan Meningkatkan Daya Saing Perusahaan. Jakarta: Raja Grafindo Persada.

Robbins, S. 2008. Perilaku Organisasi. Jilid 1 dan 11. Terjemahan oleh
Hadyana Puja Atmaja. Jakarta: Prenhallindo.

Ruvendi, Ramlan. 2005. "Imbalan dan Gaya Kepemimpinan Pengaruhnya Terhadap Kepuasan Kerja Karyawan di Balai Besar Industri Hasil Pertanian Bogor". Jurnal Ilmiah Bianiag.Vol. 01 No. 1.

Setiyawan, Budi dan Waridin. 2006. "Pengaruh Disiplin Kerja Karyawan dan Budaya Organisasi Terhadap Kinerja Di Divisi Radiologi RSUP Dokter Kariadi Semarang".Jurnal.JRBI Vol2 No 2 Hal 181-19.

Subagyo, Pangestu dan Djarwanto. 2005. Statistik Induktif. Edisi Kelima. Yogyakarta: Penerbit BPFE.

Supangat, Andi. 2008. Statistika Dalam Kajian Deskriptif, Inferensi dan Parametrik. Jakarta: Kencana Prenada.

Trianingsih, Sri. 2007. "Independensi Auditor Dan Komitmen Organisasi Sebagai Mediasi Pengaruh Pemahaman Good Governance.Gaya

Kepemimpinan Dan Budaya Organisasi Terhadap Kinerja Auditor".Jurnal Simposium AkuntasiNasional. Makasar: UNHAS.

Wirawan. 2009. Evaluasi Kinerja Sumber Daya Manusia Teori, Aplikasi, dan Penelitian. Jakarta: Salemba Empat.

Yousef, D.A. 2000. "Satisfaction with Job Security as APredictor of 
Organizational Commitment and Job Performance in A Multicultural Environment". International Journal of Man Power.Vol. 19 No. 3. pp. 184 .

Yulianto, Aan Eka. 2014. "Pengaruh Motivasi Kerja, Disiplin Kerja Dan Kepuasan Kerja Terhadap Kinerja Karyawan RS Asy-Syifa Sambi”. Skripsi. Surakarta: Universitas Muhammadiyah Surakarta.

Jurnal, Aliefia Hanifaradiz 2016, Ilmu dan Riset Manajemen, Sekolah Tinggi Ilmu Ekonomi Indonesia (STIESIA) Surabaya, "Pengaruh Gaya Kepemimpinan Terhadap Kinerja Karyawan Pada PT. Mulyo Cahya di Surabaya

Jurnal. Chamzah,( 2014 ).ISSN, UIN Syarif Hidayatullah Jakarta, "Analisis Pengaruh Komunikasi Organisasi dan Motivasi Terhadap Kinerja Karyawan di Ramayana Ciputat

Toto Widiato, (2016) yang berjudul "Pengaruh Gaya Kepemimpinan Transformasi dan Komunikasi Organisasi Terhadap Kinerja Karyawan Pada PT. Paramita Bangun Sarana di Jakarta

Ranty Sapitri, (2015) yang berjudul "Analisis Pengaruh Komunikasi Oganisasi Terhadap Kinerja Karyawan Perusahaan Listrik Negara Area Pekanbaru. 